\title{
Forest certification map of Europe
}

\author{
Mauro Maesano (1), \\ Marco Ottaviano (2), \\ Gun Lidestav ${ }^{(3)}$, \\ Bruno Lasserre ${ }^{(2)}$, \\ Giorgio Matteucci ${ }^{(4)}$, \\ Giuseppe Scarascia Mugnozza ${ }^{(5)}$, \\ Marco Marchetti ${ }^{(2)}$
}

Forests cover nearly $40 \%$ of European land, with different country percentage and patchy distribution. The European forestry sector highlights that forest areas have different ownership: private (by firms, individual, or organizations) and public (State, communities or municipalities). The number of forestry holdings, size of landholding, and ownership types influence and drive forest management, governance and various other socio-economic linked issues. Moreover, forest owners determine management objectives and policies which influence the application of Sustainable Forest Management (SFM) practices. Several tools were developed to promote SFM, including forest certification. Numerous forest certification schemes are present across the world but the Forest Stewardship Council (FSC) and the Programme for the Endorsement of Forest Certification (PEFC) are those prevalent. However, a map of certified forests is lacking, although mapping would be essential to locate the percentage of forest that are certified to be sustainably managed. The study mapped forest certification across 43 European states, according to 499 FSC and 284 PEFC reports and assessed the proportion of certified forest area on public and private land and the rate of increase. This research was carried out collecting information on European certified forest companies/owners and locating geographically their forests at sub-national level (regions, NUTS 2). The database of the Joint COST Action FACESMAP/UNECE/FAO was an important data source. At European level, about six percent of the forest is certified under FSC scheme, while about seven percent under PEFC scheme. As forest certification is a useful tool to manage forests aiming at the integration of economic, ecological and social sustainability, the knowledge of the location and area of certified forest in Europe could be important in motivating decision makers to increase these sustainably managed areas.

Keywords: Forest Policy, Sustainable Forest Management, Forest Certification, Forest Owners, Forest Management

and societal conditions that has developed throughout the history (Sands 2005). At the European Union (EU) level, each member state defines its forest management approaches and forest policies (Edwards \& Kleinschmit 2013, Vuletic et al. 2010). In fact, the EU does not provide for a common forestry policy, but supports forestry sustainability through many policy frame- $\square$ (1) National Research Council of Italy (CNR), Institute for Agricultural and Forestry Systems in the Mediterranean (ISAFOM), v. Cavour, 4-6 I-87036 Rende, CS (Italy); (2) Department of Bioscience and Territory (DiBT), University of Molise, c.da Fonte Lappone snc, I-86090 Pesche, IS (Italy); (3) Department of forest resource management, Swedish University of Agricultural Sciences (SLU), 90183 Umeå (Sweden); (4) National Research Council of Italy (CNR), Institute for Agricultural and Forestry Systems in the Mediterranean (ISAFOM), v. Patacca 85, I-80056 Ercolano, NA (Italy); (5) Department of Innovation in Biological, Agro-Food and Forest System (DIBAF), University of Tuscia, v. San Camillo de Lellis, I-01100 Viterbo, VT (Italy)

@ Mauro Maesano (mauromaesano@gmail.com)

Received: Oct 26, 2017 - Accepted: May 16, 2018

Citation: Maesano M, Ottaviano M, Lidestav G, Lasserre B, Matteucci G, Scarascia Mugnozza G, Marchetti M (2018). Forest certification map of Europe. iForest 11: 526-533. - doi: 10.3832/ifor2668-011 [online 2018-08-01]

Communicated by: Agostino Ferrara works including the EU Forestry Strategy (1998) and the EU Forest Action Plan (2006) defined with the Member States through the Standing Forestry Committee. In this context, Sustainable Forest Management (SFM) has become a recognized and widely spread concept both for the national forest plans and in the international forest policy (McDonald \& Lane 2004) for the safeguarding the different values and services provided by forests to the community (Harshaw et al. 2009) and as a management system that seeks to balance social needs, economic aspects and ecological values associated with the forest, with consideration of future generations (Hickey 2008). SFM is a complex term and includes the entire forest ecosystem (Schall \& Ammer 2013) which currently is assessed through several Principles, Criteria and Indicators (Levers et al. 2014). The present challenge of SFM is to take into account the multiple functions and services provided by forest to the society. The identification of these functions in forest management is important for assessing the environmental trade-offs of forestry (Levers et al. 2014), where applying SFM means maintaining multi-functionality of forest (Yamada 2018). Establishment of the framework 
of Criteria and Indicators based on sustain ability Principles is a powerful tool for implementing SFM (Wijewardana 2008, Martín-Fernández \& Martinez-Falero 2018). At the European level, many processes of international politics have influenced the evolution of the multifunctional framework of SFM. In the last years, FOREST EUROPE developed common strategies for protecting and sustainably manage forests through a participatory process, involving 46 participating countries in defining Criteria and qualitative and quantitative Indicators (CI-SFM project - http://www.ci-sfm. org). However, different obstacles in the efficient implementation of SFM Principles can occur, including ownership structure and fragmentation of forest properties.

Forest areas are privately owned by firms, individual, or organizations and publicly owned by State, communities or municipalities. According to different management objectives, ownership types and number of forestry holdings can influence forest management and connected socio-economic values (Whiteman et al. 2015). In Europe, 107 million hectares, or $52 \%$ of all forestland, are in hands of private owners (Forest Europe 2015). The majority, close to 16 million of individuals are so called non-in-

Tab. 1 - Official number of second level NUTS in each country (source: http://ec. europa.eu - updated: June 2014).

\begin{tabular}{|c|c|c|}
\hline Country & $\begin{array}{l}\text { Country } \\
\text { Code }\end{array}$ & $\begin{array}{c}\text { no. NUTS } \\
2^{\circ} \text { level }\end{array}$ \\
\hline Austria & AT & 9 \\
\hline Belgium & $\mathrm{BE}$ & 11 \\
\hline Bulgaria & BG & 6 \\
\hline Cyprus & CY & 1 \\
\hline Czech Republic & $C Z$ & 8 \\
\hline Germany & DE & 38 \\
\hline Denmark & DK & 5 \\
\hline Estonia & $\mathrm{EE}$ & 1 \\
\hline Greece & EL & 13 \\
\hline Spain & ES & 19 \\
\hline Finland & $\mathrm{FI}$ & 5 \\
\hline France & FR & 26 \\
\hline Croatia & HR & 2 \\
\hline Hungary & $\mathrm{HU}$ & 7 \\
\hline Ireland & IE & 2 \\
\hline Italy & IT & 21 \\
\hline Lithuania & LT & 1 \\
\hline Luxembourg & LU & 1 \\
\hline Latvia & LV & 1 \\
\hline Malta & MT & 1 \\
\hline Netherlands & NL & 12 \\
\hline Poland & PL & 16 \\
\hline Portugal & PT & 7 \\
\hline Romania & RO & 8 \\
\hline Sweden & SE & 8 \\
\hline Slovenia & SI & 2 \\
\hline Slovakia & SK & 4 \\
\hline United Kingdom & UK & 37 \\
\hline Switzerland & $\mathrm{CH}$ & 7 \\
\hline Iceland & IS & 1 \\
\hline Liechtenstein & LI & 1 \\
\hline Montenegro & ME & 1 \\
\hline Macedonia & MK & 1 \\
\hline Norway & NO & 7 \\
\hline Turkey & TR & 26 \\
\hline Andorra & AND & 1 \\
\hline
\end{tabular}

dustrial private forest (NIPF) owners, but in some countries like Sweden, Finland and Portugal there are also private corporations owning and managing large areas of forest land (Zivojinović et al. 2015). Thus, private forest owners play a crucial role in European forestry, although most of them are managing very small forestlands ( $\mathrm{Di}$ Lallo et al. 2016).

SFM is a complex term and includes the entire forest ecosystem (Schall \& Ammer 2013) which currently is assessed through several Indicators (Levers et al. 2014) and Principles. In recent years, the SFM concept in the private and public sectors has been extensively discussed and to promote SFM several tools have been developed, including forest certification (Durst et al. 2006). Forest certification is a voluntary instrument created in the ' 90 s to respond to the degradation of forests and to reduce illegal deforestation or mis-use of forests (Cashore et al. 2006). Certification aims to ensure that management is undertaken through the observance of Forest Management (FM) standards, improving forest practices in environmentally sustainable, socially and economically viable ways. Numerous forest certification schemes are present across the world, but the Forest Stewardship Council (FSC) and the Programme for the Endorsement of Forest Certification (PEFC) are among the most recognized and diffused. Both schemes promote environmentally sustainable, socially responsible and economically viable forest management and they have been widely adopted in developed countries, particularly in Europe (Chen \& Innes 2013). Certification can improve forest management, allowing both consumers and companies to have an important role in forest conservation through their choice of certified products (Gafo Gomez-Zamalloa et al. 2011). Certified forests respect an agreed and strict forest management standards, guaranteeing well- and sustainably-managed forests. Forests with a good management contribute positively to local sustainable development and promote the mitigation of climate change effects at large scale (Martínez-Vega et al. 2016).

The FSC sets out the global requirements (Principles \& Criteria) for achieving FSC forest management certification. Thereafter, the National Standards Development Groups adapt the FM standard at the regional and/or national level, in order to reflect the diverse legal, social and geographical conditions of forests in different parts of the world, creating a local standard based on global principles. Nineteen National FSC Standards are present in Europe, and Certification Body interim standards are operational in countries where these have yet to be developed.

The PEFC is an umbrella organization that endorses national forest certification systems. Twenty-four Council Members have been endorsed by the PEFC in Europe. Stakeholders interested in forests and for- estry are actively involved in the forest certification process and in the standards definition through participatory approaches. Therefore, it is important for forest certification process to inform local residents and stakeholders on forest management issues and their opportunities for participation. As reported by Romero et al. (2013) many forest stakeholders now agree on the need to assess where, how, and to what extent the certification changed the ways of managing forests. Numerous studies have compared forest certification schemes, particularly on the basis of the stringency of their standards, and operational modes (Auld et al. 2008, Johansson \& Lidestav 2011, Romero et al. 2013). Yet, the identification, quantification and mapping of certified forest areas according to certification schemes as well as by ownership categories needs to be improved. There is a growing concern about forest sustainability and data presented in the form of maps represent powerful sources of information, which can support international process, policy-making, decisionmaking, research activities as well as forest planning at various level (Maesano et al. 2016).

The principal aim of the research presented in this paper is to develop maps on the forest certification diffusion in Europe by FSC and PEFC standards and geographically locate the certified forests at sub-national level. Another objective was to assess the proportion of certified forest area on public compared to private land and the rate of increase. These aims were pursued as maps can be a tool for promoting the sharing of data, to have more information on the forest certified areas geolocalization (Kraxner et al. 2017) to promote the Sustainable Forest Management and to encourage more transparent processes both for producers and users.

\section{Material and methods}

In order to develop the maps, a large set of data from European FSC and PEFC reports was collected and elaborated in a GIS (Geographic Information System) environment at the NUTS (Nomenclature of Territorial Units for Statistics) 2 level (i.e., Regions). The NUTS classification is a hierarchical system for dividing the economic territory of the EU for the purpose of the collection, development and harmonisation of European Union regional statistics, socioeconomic analyses of the regions and the framing of EU regional policies.

The research process was divided in three stages. In the initial stage, a shapefile for all countries of the European region was created. In the second one, the database of certified forests in Europe (from the geographical point of view) for both FSC and PEFC was built, and in the final stage, the data were elaborated and the map of certified forests in Europe was completed.

In the forest certification map, national and sub-national boundaries, correspond- 
ing to the second level of NUTS classification, were used. The NUTS geo-data file was downloaded from the European Commission website (2010 update - "European NUTS layer") and includes 36 countries (Tab. 1). For countries not covered by NUTS geo-data, sub-national boundaries were taken into account. In this case, to identify the exact location of the forests, a code ("European boundaries layer" - shapefile), similar to that of the NUTS code, was created for each area (Tab. 2). For Russia, only the European part was considered (up to the Urals mountain range). Subsequently, to identify the different boundaries of European countries, a new shapefile was created by the integration of the "European NUTS layer" and "European boundaries layer" at sub-national level using the QGis Software. The new shapefile includes all countries present in European area (Fig. 1).

The data of certified forests areas were collected in June 2014 from FSC (http://in fo.fsc.org/) and PEFC (http://www.pefc regs.info/) on-line database, and were imported into a spread sheet. The structure of the database was made according to the data present on freely available public reports. In fact, FSC certification requires forest managers and auditors to make auditing and monitoring reports publicly available (FSC 2014), while in PEFC certification only the principal data on the forests and owners are published on-line. Even if several Certification Bodies have different FSC report templates, the basic information required by FSC is always present. The data taken into account by two schemes were: type of certification scheme, country, NUTS ID, certificate code, license code, owner name, owner address, certification type, SLIMFs (Small and Low Intensity

Tab. 2 - Countries not covered by NUTS geo-data added to the second NUTS layer.

\begin{tabular}{llcl}
\hline Country & Country Code & $\begin{array}{c}\text { No. Sub } \\
\text { National Levels }\end{array}$ & Code \\
\hline Albania & AL & 26 & From AL01 to AL26 \\
Belarus & BLR & 6 & From BLR1 to BLR6 \\
Bosnia-Herzegovina & BIH & 1 & BIH1 \\
Georgia & GEO & 3 & From GE01 to GEO3 \\
Moldova & MD & 1 & MD01 \\
Russia (EU) & RU & 54 & From RU01 to RU54 \\
Ukraine & UA & 25 & From UA01 to UA25 \\
\hline
\end{tabular}

Managed Forests), certification body, total forest area, High Conservation Values ( $\mathrm{HCV}_{1}, \mathrm{HCV}_{2}$. HCV $3, \mathrm{HCV}_{4}, \mathrm{HCV}_{5}, \mathrm{HCV} 6-$ Maesano et al. 2016), NUTS name, NUTS code and number of schemes.

In this study, the certified area according to the two schemes were maintained separated because the exact location of the forest is given in the FSC reports but not in the PEFC reports. In the latter, the location of the forest owner is reported, but without information on the ownership type.

Data on certified area by ownership categories, and certification trends, was retrieved from Joint COST Action FACESMAP/ UNECE/FAO Enquiry on Forest Ownership in the ECE Region. The enquiry was launched in May 2015 and directed to the UNECE/FAO national correspondents and the COST Action FACESMAP respondents, who were asked to respond by the end of October 2015. One of the eleven topics in the survey contained questions on certified area by ownership categories in 2010 and 2015. Out of the 32 addressed countries, 14 countries provided complete answers on this issue and another four gave partial in- formation. Thus, the full picture is not at hand, but the provided specific data on ownership still reveals some general features on the development of forest certification.

For each polygon of the NUTS 2 level, the percentage of certified forest was calculated considering the total forest area from the Corine Land Cover (CLC update 2012, scale: 1:100.000, Minimum Mapping Unit: 25 hectares). The CLC maps are available for: Austria, Belgium, Bosnia and Herzegovina, Bulgaria, Croatia, Czech Republic, Denmark, Estonia, Finland, France, Germany, Hungary, Ireland, Italy, Lithuania, Luxembourg, Netherlands, Norway, Poland, Portugal, Romania, Slovakia, Slovenia, Spain, Sweden, Switzerland, Turkey and United Kingdom. Instead, data from Forest Europe (Forest Europe/UNECE/FAO 2011) and FAO (FRA 2005) on the total forest area was respectively considered for Russia and Belarus.

The CLC classes related to forests and Others Wooded Land (OWL) categories were taken into account for each European Country and then joined into a single layer.

Fig. 1 - Shapefile from two layers: "Official European NUTS layer" and "European boundaries layer".

European countries involved in this project.

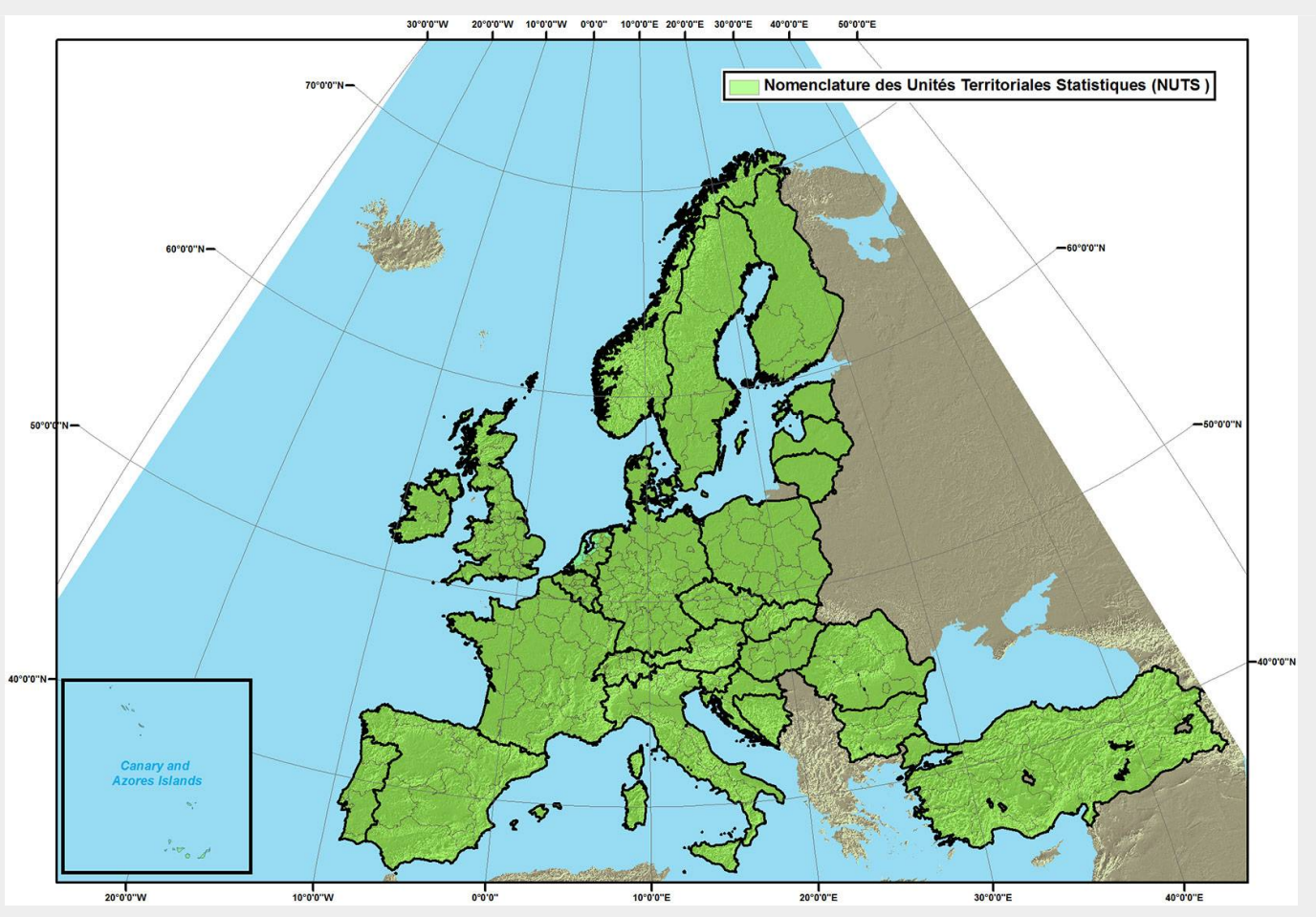




\begin{tabular}{|c|c|c|c|c|c|}
\hline Country & $\begin{array}{c}\text { Total Forest Area [ha] } \\
\text { Certified by FSC }\end{array}$ & $\begin{array}{l}\text { Total Forest Area [ha] } \\
\text { Certified by PEFC }\end{array}$ & Forest Area [ha] ${ }^{1}$ & $\%$ FsC & \% PEFC \\
\hline Austria & 575 & $2,755,452$ & $3,984,766$ & $0.01 \%$ & $69.15 \%$ \\
\hline Belarus $^{2}$ & $4,901,127$ & $8,397,100$ & $8,808,000$ & $55.64 \%$ & $95.33 \%$ \\
\hline Belgium & 20,910 & 289,050 & 644,316 & $3.25 \%$ & $44.86 \%$ \\
\hline Bosnia-Herzegovina & $1,519,235$ & 0 & 2825610.66 & $53.77 \%$ & $0.00 \%$ \\
\hline Bulgaria & 409,674 & 0 & $4,243,943$ & $9.65 \%$ & $0.00 \%$ \\
\hline Croatia & $2,038,296$ & 0 & $2,765,570$ & $73.70 \%$ & $0.00 \%$ \\
\hline Czech Republic & 49,544 & $1,845,321$ & $2,781,117$ & $1.78 \%$ & $66.35 \%$ \\
\hline Denmark & 199,557 & 253,285 & 513,380 & $38.87 \%$ & $49.34 \%$ \\
\hline Estonia & $1,177,048$ & $1,836,260$ & $2,507,262$ & $46.95 \%$ & $73.24 \%$ \\
\hline Finland & 461,787 & $19,687,046$ & $24,710,879$ & $1.87 \%$ & $79.67 \%$ \\
\hline France & 19,827 & $7,930,166$ & $16,484,273$ & $0.12 \%$ & $48.11 \%$ \\
\hline Germany & 971,913 & $7,350,877$ & $10,686,950$ & $9.09 \%$ & $68.78 \%$ \\
\hline Hungary & 320,963 & 0 & $2,025,927$ & $15.84 \%$ & $0.00 \%$ \\
\hline Ireland & 447,219 & 0 & 754,069 & $59.31 \%$ & $0.00 \%$ \\
\hline Italy & 50,944 & 778,356 & $10,055,403$ & $0.51 \%$ & $7.74 \%$ \\
\hline Latvia & $1,749,109$ & $1,683,641$ & $3,257,020$ & $53.70 \%$ & $51.69 \%$ \\
\hline Lithuania & $1,066,170$ & 0 & $2,112,123$ & $50.48 \%$ & $0.00 \%$ \\
\hline Luxembourg & 20,535 & 31,185 & 94,023 & $21.84 \%$ & $33.17 \%$ \\
\hline Nederland & 125,734 & 0 & 353,444 & $35.57 \%$ & $0.00 \%$ \\
\hline Norway & 346,385 & $9,098,302$ & $16,009,703$ & $2.16 \%$ & $56.83 \%$ \\
\hline Poland & $6,879,591$ & $7,304,356$ & $9,705,967$ & $70.88 \%$ & $75.26 \%$ \\
\hline Portugal & 336,838 & 236,385 & $3,993,956$ & $8.43 \%$ & $5.92 \%$ \\
\hline Romania & $2,554,089$ & 0 & $7,662,622$ & $33.33 \%$ & $0.00 \%$ \\
\hline Russia $^{3}$ & $25,541,794$ & $2,018,554$ & $882,170,000$ & $2.90 \%$ & $0.23 \%$ \\
\hline Slovakia & 142,483 & $1,242,760$ & $2,198,592$ & $6.48 \%$ & $56.53 \%$ \\
\hline Slovenia & 249,649 & 10,210 & $1,202,073$ & $20.77 \%$ & $0.85 \%$ \\
\hline Spain & 194,284 & $1,689,975$ & $19,906,722$ & $0.98 \%$ & $8.49 \%$ \\
\hline Sweden & $12,054,376$ & $9,812,789$ & $32,339,842$ & $37.27 \%$ & $30.34 \%$ \\
\hline Switzerland & 695,871 & 182,377 & $1,370,514$ & $50.77 \%$ & $13.31 \%$ \\
\hline Turkey & $2,908,707$ & 0 & $20,480,747$ & $14.20 \%$ & $0.00 \%$ \\
\hline Ukraine $^{3}$ & $1,401,352$ & 0 & $9,274,000$ & $15.11 \%$ & $0.00 \%$ \\
\hline United Kindom & $1,560,434$ & $1,351,505$ & $4,553,679$ & $34.27 \%$ & $29.68 \%$ \\
\hline Europe & $70,416,019$ & $85,784,952$ & & & \\
\hline
\end{tabular}

Fig. 2 - Percentage of certified forest area for each country.

The forest cover within each NUTS II level was obtained through overlapping of the NUTS layer with CLC layer. At this stage, the statistics on certified forest for each NUTS II in Europe were analyzed and compared at European level.

\section{Results and discussion}

According to the data, European FSC certified forest area at 2014 was about $70,416,000$ hectares (Fig. 2). Among the 499 analysed FSC reports, 5 were certified as Forest Management - FM (nearly
$50,000 \mathrm{ha}$ ) and 494 as Forest Management and Chain of Custody - FM/COC (about $70,366,000 \mathrm{ha})$. Regarding the type of certification, 363 were single certification (about 59,916,000 ha) and 136 were group certification (about 10,500,000 ha). Further, 284 PEFC reports were explored; whereof 97 were single certification (about 10,906,000 ha), 112 were group certification (about 30,241,000 ha) and 75 were regional certification (about 44,638,000 ha).

Regarding the percentage of certified forest, approximately $6 \%$ (or $70,416,000$ ha -
Fig. 3) of the overall forest area at European level is certified under the FSC scheme, while about $7 \%$ (or $85,785,000$ ha) are certified under the PEFC scheme (Fig. 4). The countries with the highest certified areas was Croatia with about $73 \%$ of total forest area certified according to FSC standard, and Belarus, with about $95 \%$ of forest PEFC certified (Fig. 2). At NUTS level, the percentage of FSC certified forest largely varies (Fig. 5). The highest values were found in Poland, inside of PL22 and PL61, with all forests that resulted FSC-certified

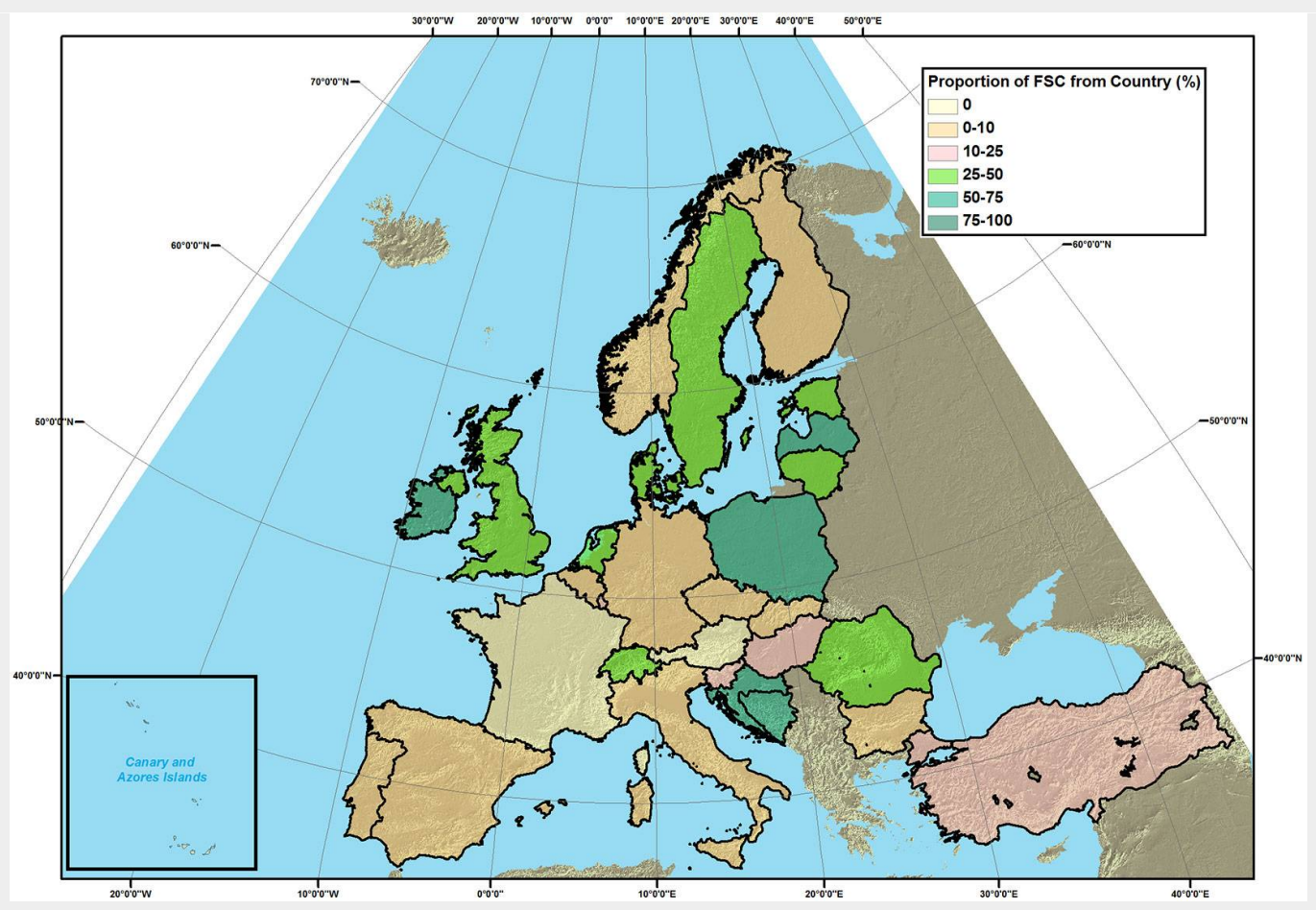

Fig. 3 - Percentage of certified forest area for each country under FSC scheme. 
Fig. 4 - . Percentage of certified forest area for each country under PEFC scheme.

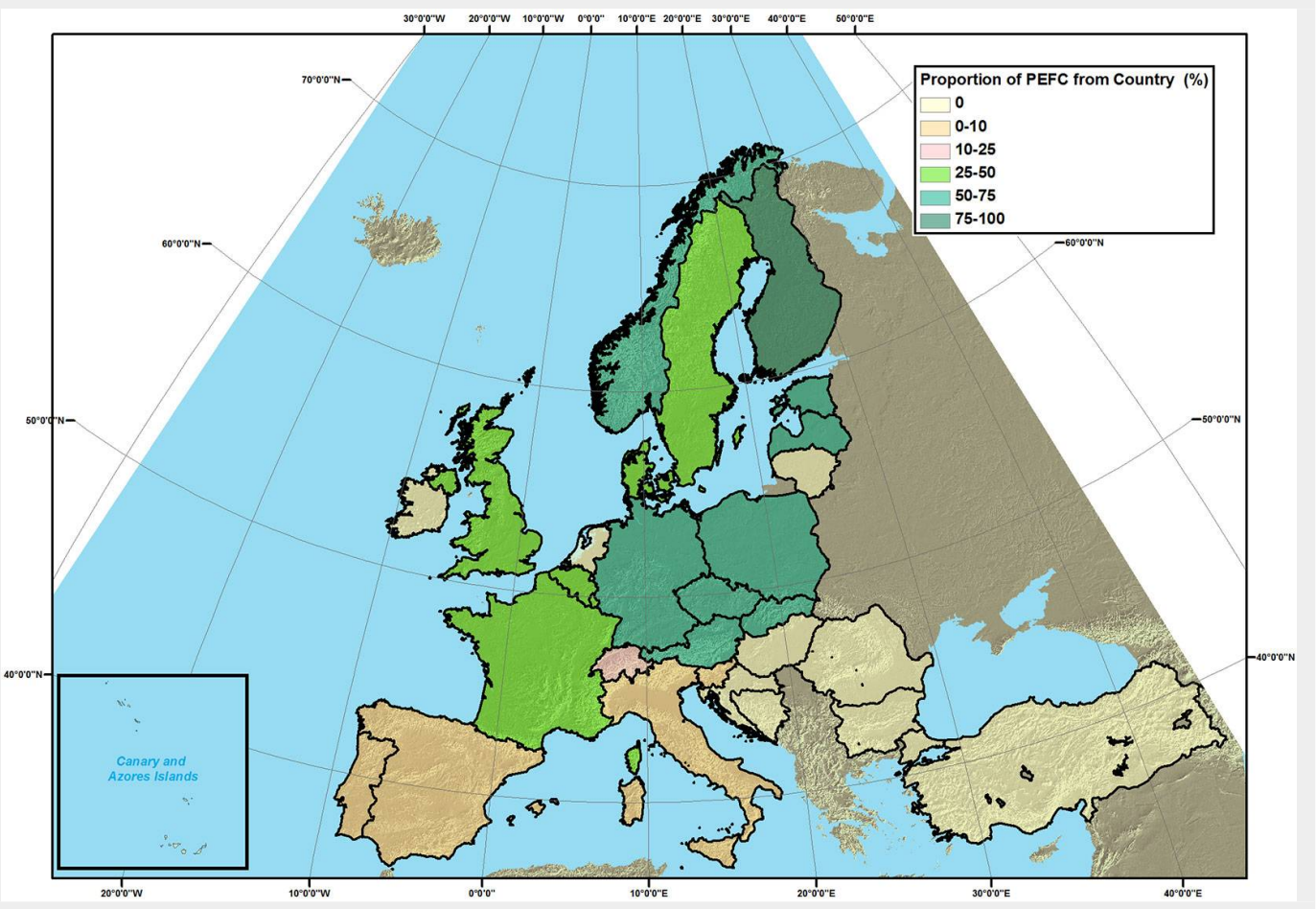

forests (Fig. 3). In general, one certification system is predominant in a given country, in line with the observation by Gafo Gomez-Zamalloa et al. (2011) that reported that each EU Member State has opted for one or the other certification system. However, some forestland are certified simultaneously by both systems.

While in some European countries like Poland, Latvia, Denmark and Estonia, there is a significant interest in both schemes, other countries as Austria, Croatia, Finland, Ireland, demonstrate a pronounced prefer- ence for one of the two (Fig. 2). In the case of Poland, Latvia and Estonia the choice is related to government decision that requested the FSC forest management certification as a solution to specific policy problems (Cashore et al. 2006): this resulted in a great increase in certified forest area.

In this study, certified forests have a total amount lower $(<35 \%)$ than the one officially reported by FSC (2014) because in the present study Russia was considered only in part (European Russia). If we consider the certified forest area without Russia, we get the same area (about 44 milion ha) reported by FSC in 2014. On the other hand, European PEFC certified forest area was $85,784,952$ hectares. Data on total forest area in Europe is derived from Corine Land Cover and differences exist between CLC results and other statistics collected with different methodologies such as Forest Europe - State of Europe's forest; this is often the case for agriculture and forest statistics.

Each European country has a percentage

Fig. 5 - Percentage of certified forest area for each NUTS II Level under FSC scheme.

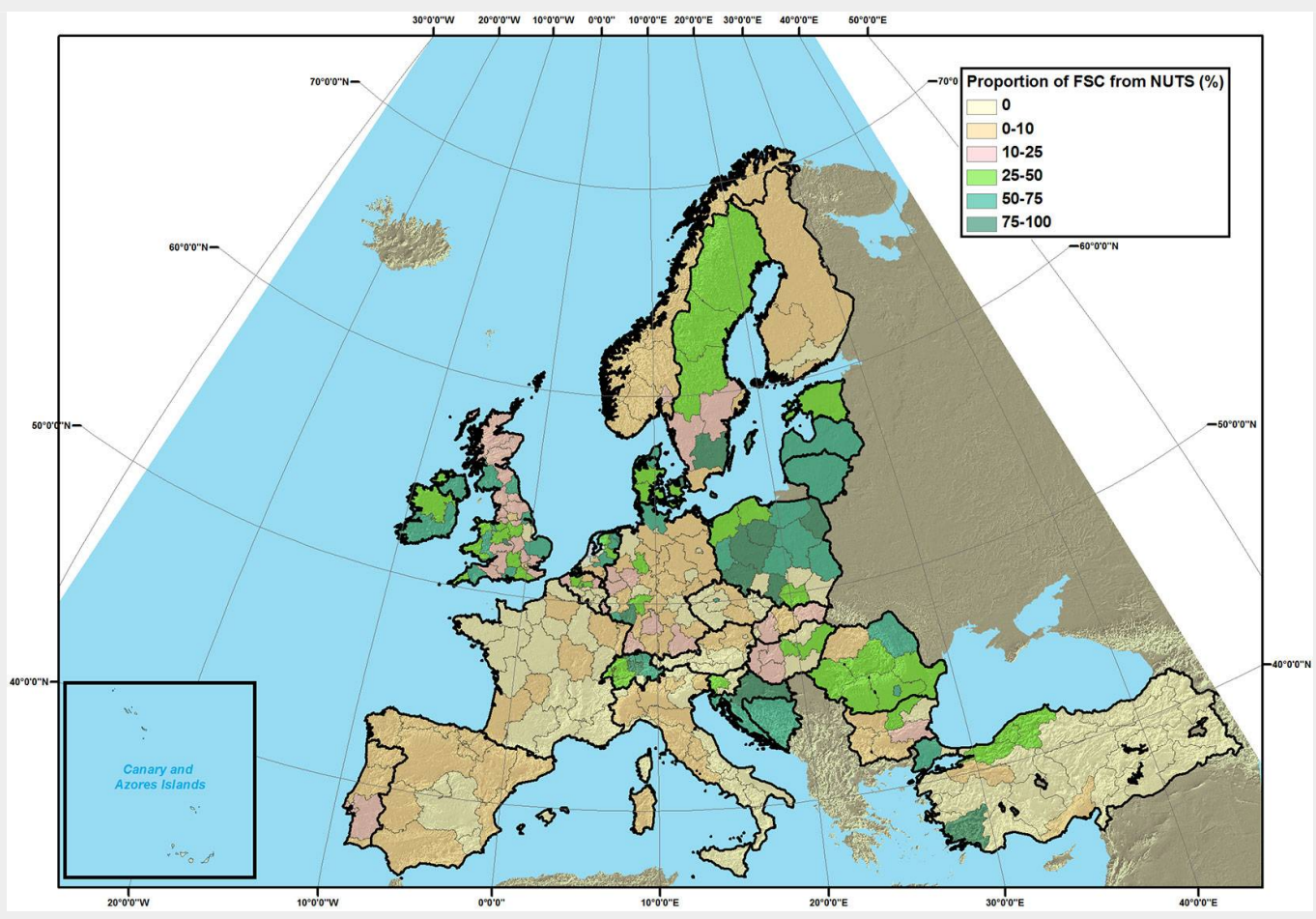


Tab. 3 - Proportion of certified forest land in some ECE countries. Source; Joint COST Action FACESMAP/UNECE/FAO Enquiry on For est Ownership in the ECE Region.

\begin{tabular}{|c|c|c|c|c|c|c|c|c|}
\hline \multirow[b]{2}{*}{ Country } & \multicolumn{3}{|c|}{ Public Forest } & \multicolumn{3}{|c|}{ Private Forest } & \multicolumn{2}{|l|}{ Total } \\
\hline & $\begin{array}{l}\text { Prop. } \\
\text { Certified } \\
2010(\%)\end{array}$ & $\begin{array}{l}\text { Prop. } \\
\text { Certified } \\
2015 \text { (\%) }\end{array}$ & $\begin{array}{l}\text { Change } \\
2010-2015\end{array}$ & $\begin{array}{l}\text { Prop. } \\
\text { Certified } \\
2010(\%)\end{array}$ & $\begin{array}{l}\text { Prop. } \\
\text { Certified } \\
2015 \text { (\%) }\end{array}$ & $\begin{array}{l}\text { Change } \\
2010-2015\end{array}$ & $\begin{array}{l}\text { Forest area } \\
1000 \text { ha }\end{array}$ & $\begin{array}{l}\text { Prop. } \\
\text { Certified } \\
2015 \text { (\%) }\end{array}$ \\
\hline Austria & 67 & 67 & 0 & 47 & 75 & +31 & $3,869.0$ & 74 \\
\hline Belgium & 85 & 87 & +2 & 7 & 11 & +4 & 683.0 & 47 \\
\hline Bulgaria & 9 & 24 & +15 & 0 & 1 & +1 & $3,812.0$ & 21 \\
\hline Croatia & 94 & 95 & +1 & 0 & 0 & 0 & $1,922.0$ & 67 \\
\hline Cyprus & 0 & 0 & 0 & 0 & 0 & 0 & 172.7 & 0 \\
\hline Finland & - & 72 & - & - & 90 & - & $22,218.0$ & 85 \\
\hline France & 74 & 82 & +8 & 17 & 18 & +1 & $16,988.0$ & 33 \\
\hline Iceland & 0 & 0 & 0 & 0 & 0 & 0 & 49.1 & 0 \\
\hline Ireland & 100 & - & - & 2 & - & - & 726.0 & - \\
\hline Luxembourg & 0 & 87 & +87 & 0 & 6 & +6 & 88.7 & 44 \\
\hline Netherlands & - & 62 & - & - & 28 & - & 376.5 & 45 \\
\hline Russia & 3 & 5 & +2 & 0 & 0 & 0 & $814,930.5$ & 5 \\
\hline Serbia & 27 & 88 & +61 & - & - & - & $2,720.0$ & 37 \\
\hline Slovakia & 0 & 96 & +96 & 0 & 37 & +37 & $1,942.0$ & 60 \\
\hline Slovenia & 79 & 82 & +3 & 0 & 6 & +6 & $1,248.0$ & 24 \\
\hline Switzerland & 85 & 86 & +1 & 48 & 44 & -4 & $1,254.0$ & 55 \\
\hline Turkey & 0 & 19 & +19 & 0 & 0 & 0 & $12,666.2$ & 19 \\
\hline United Kingdom & 100 & 100 & 0 & 22 & 22 & 0 & $3,154.0$ & 44 \\
\hline
\end{tabular}

of certified forest under the FSC scheme, while some countries (Bulgaria, Portugal, Turkey, Bosnia-Herzegovina, Croatia, Hungary, Ireland, Lithuania, Nederland, Romania and Ukraine) do not have any certified forest under the PEFC scheme. The spread of one scheme with respect to the other (FSC or PEFC), depends on many factors, including the distribution on ownership type, their management objectives and connections to the market for timber and non-timber forest products. Many companies, for example in Italy and Sweden, choose to be certified under both schemes for the chance to sell certified products according to the requests of the buyer and market trends, since the two schemes have not mutual recognition. Moreover, forest fragmentation seems to be an important factor, which affects not only the readiness to certify the forest, but also the choice of scheme. In relation to the perceived benefits, the certification process is often expensive in terms of cost and organizational effort for small forest owners (Zhao et al. 2011). As reported by Di Lallo et al. (2016), certification costs are the most critical limiting factor for smallholders. In Europe, the exact forest area managed by small forest owners is unknown, but it is estimated to represent about $60 \%$ of the total forest area (UNFF-11 2015, Di Lallo et al. 2016). Currently, for both schemes, facilitations exist for smallholders, such as the Small or LowIntensity Managed Forests program from FSC or the "group certification" that, under both schemes, allows a group of forest owners to join together to get the certification. However, results from the Joint COST Action FACESMAP/UNECE/FAO Enquiry indicates that the proportion of certified for- est land is usually higher on public forest land that on private forest land (Tab. 3). Interesting exceptions are Austria and Finland, with a higher level of certified private forest land. One possible explanation for Austria might be the increased use of wood due to public relations campaigns conducted since the early 1990s (Rametsteiner \& Kraxner 2003), whereas for Finland, could be that the majority of forest owner's (about 70\%) is living in rural areas (Hirsch et al. 2007). Further, it is worth noting that there is an increasing trend in certification from 2010 to 2015, both on public and private land. In few countries, like Ireland and UK, all public forest land was certified already in 2010, while in Luxembourg, Slovak and Turkey no forest land was certified in 2010.

\section{Conclusions}

Over the recent years, the sensitivity of world public opinion on the issues of sustainable forest management in light of climate change and the resulting impacts has increased. Forests provide several ecosystem services from timber and non-wood forest products to carbon sequestration and recreation for human well-being (Millennium Ecosystem Assessment 2005). Indeed, in the last years, the focus of forest management has been shifted from timber to a broader range of values (McFarlane \& Boxall 2000), through innovative forest governance approaches with mutual interactions of public and private actors (Secco et al. 2015). Forest certification promotes a forest management that is economically, socially and environmentally viable, and contributes to the preservation of ecosystem services provided by forest, also con- sidering mitigation of climate change. Nevertheless, FSC forest management certification is linked also to forest ecosystem services in terms of biodiversity conservation, carbon storage, Non-timber forest products provision, watershed protection services and ecotourism values (Jaung et al. 2016). Forest certification, although of voluntary nature, is one of the few tools currently existing that provides guarantee on Sustainable Forest Management and that, thanks to the Chain of Custody ( $\mathrm{COC}$ ) standard, ensure the traceability of forest products, from harvesting to finished products (Ilarioni et al. 2013). Forest certification process requires a forest management plan that has to include strategies for monitoring management practices to ensure that sustainabil-ity requirements are met (Harshaw et al. 2009).

FSC is a worldwide initiative, centralized and based on global Principles, while PEFC is an international membership association that adopted a bottom-up approach to governance and recognizes the activities of some autonomous certification schemes across the world.

Globally, the annual growth in area of certified forests has been quite constant.

This report analysed the situation in European countries. Within the FSC database, the public report summary of the main audit and sometimes others documents (surveillance audit, notes, etc.) are made available, while in the PEFC database only the main data of the certification are shown. A critical issue into the study process was to define the exact location of the certified forests. On the FSC online database, summaries of audit reports are publicly available, but each certification body employs a 
different template. It would be appropriate to create a common template or at least some common information by all the certification bodies to have a greater transparency and a better usability of data. Regarding PEFC database, there are no-exact location about the forests areas in the free available reports, but the location of the certificate holder is indicated. Further, CLC uses a Minimum Mapping Unit of 25 hectares and this implies that smaller areas of certain forests may not be adequately detected.

The forest certification map of Europe is certainly a useful starting point for understanding the network of the certified forests. Keeping it up to date, the map will allow to quantify geographically location changes over time of the forest certified and to assess if management options, property or other factors may affect the spread of forest certification in the future.

Increasing the forest products from sustainably managed forest and expanding the forest areas sustainably managed represent one of the four Global Objectives discussed in the UN Forum on Forests. Forests are vital for creating green economies, including green industries. In this forum, the green economy concept has been considered a major tool for achieving sustainable development and eradicating poverty for the more vulnerable categories of people, such as indigenous communities and women (UNFF-11 2015). Well-managed forests have tremendous potential to contribute to sustainable development and to a greener economy. Forest certification is widely recognized as a useful tool for moving towards SFM (Durst et al. 2006) aiming at the integration of economic, ecological and social sustainability (Papilla 2013) expecially in terms of community and workers' rights (Cashore et al. 2006). Forest certification can be considered one of the first examples of a shift from a state-centred governance of forest resources to nonstate actors' participation in forestry governance (Hackett 2013).

Which are the principal causes of the nonhomogeneous geographical distribution in certified forest areas is an open question. One important factor is undoubtedly national public authorities and their respective forest laws, but also the different market conditions in European countries have a great importance. In effect, while forest certification is growing in much of the world regions, it does not yet appear to be deeply supported by local government policies (Cashore et al. 2006). Knowing how much forest is certified in Europe and the economic, environmental and social benefits deriving from being certified could be the driver to motivate some European forest owner to become certified. In this respect, the availability of a dynamic map could be an additional tool to promote and spread certification in Europe and beyond.

iForest 11: 526-533

\section{Acknowledgements}

This research was funded through STSM program by COST-ACTION FP1201 "Forest land ownership change in Europe: significance for management and policy" FACESMAP. More information: http://faces map.boku.ac.at/

\section{References}

Auld G, Gulbrandsen LH, McDermott CL (2008). Certification schemes and the impacts on forests and forestry. Annual Review of Environment and Resources 33: 187-211. - doi: 10.1146/ annurev.environ.33.013007.103754

Cashore B, Gale F, Meidinger E, Newsom D (2006). Forest certification in developing and transitioning countries: part of a sustainable future? Environment: Science and Policy for Sustainable Development 48 (9): 6-25. - doi: 10.3200/ENVT.48.9.6-25

Chen J, Innes J (2013). The implications of new forest tenure reforms and forestry property markets for sustainable forest management and forest certification in China. Journal of Environmental Management 129: 206-215. - doi: 10.1016/j.jenvman.2013.07.007

Di Lallo G, Maesano M, Masiero M, Scarascia Mugnozza G, Marchetti M (2016). Analyzing strategies to enhance small and low intensity managed forests certification in Europe using SWOT-ANP. Small-scale Forestry 15: 393-411. doi: 10.1007/s11842-016-9329-y

Durst PB, Mckenzie PJ, Brown CL, Appanah S (2006). Challenges facing certification and ecolabelling of forest products in developing countries. International Forestry Review 8 (2): 193200. - doi: 10.1505/ifor.8.2.193

Edwards P, Kleinschmit D (2013). Towards a European forest policy - conflicting courses. Forest Policy and Economics 33: 87-93. - doi: 10.1016/j.forpol.2012.06.002

Forest Europe (2015). State of Europe's Forests 2015. Ministerial Conference on the Protection of Forests in Europe, Forest Europe Liaison Unit Madrid, Spain, pp. 314.

Forest Europe/UNECE/FAO (2011). State of Europe's Forests 2011. Status and trends in sustainable forest management in Europe. Ministerial Conference on the Protection of Forests in Europe, Forest Europe Liaison Unit, Oslo, Norway, pp. 344

FRA (2005). Global forest resources assessment 2005. Progress towards sustainable forest management. FAO Forestry Paper 147, Food and Agriculture Organization of the United Nations, Rome, Italy, pp. 350.

FSC (2014). Global FSC certificates: type and distribution. Web site. [online] URL: http://ic.fsc. org/en/facts-and-figures

Gafo Gomez-Zamalloa M, Caparros A, San-Miguel Ayanz A (2011). 15 years of forest certification in the European Union. Are we doing things right? Forest Systems 20 (1): 81-94. - doi: 10.5424/fs/2011201-9369

Hackett R (2013). From government to governance? Forest certification and crisis displacement in Ontario, Canada. Journal of Rural Studies 30: 120-129. - doi: 10.1016/j.jrurstud.2013.01. 003

Harshaw HW, Sheppard SRJ, Jeakins P (2009). Public attitudes toward sustainable forest man- agement: opinions from forest-dependent communities in British Columbia. BC Journal of Ecosystems and Management 10 (2): 81-103. [online] URL: http://jem-online.org/index.php/ jem/article/view/422

Hickey GM (2008). Evaluating sustainable forest management. Ecological Indicators 8 (2): 109114. - doi: 10.1016/j.ecolind.2006.11.011

Hirsch F, Korotkov A, Wilnhammer M (2007). Private forest ownership in Europe. Unasylva 228: 58: 23-25. [online] URL: http://www.fao.org/ tempref/docrep/fao/010/a1346e/a1346eo6.pdf Ilarioni L, Nasini L, Regni L, Brunori A, Proietti P (2013). Certificazione forestale come strumento della gestione sostenibile di foreste e piantagioni [Forest certification as an instrument for the sustainable management of forests and plantations. [in Italian]

Jaung W, Putzel L, Bull GQ, Kozak R, Elliott C (2016). Forest Stewardship Council certification for forest ecosystem services: an analysis of stakeholder adaptability. Forest Policy and Economics 70: 91-98. - doi: 10.1016/j.forpol.2016.06. 004

Johansson J, Lidestav G (2011). Can voluntary standards regulate forestry? Assessing the environmental impacts of forest certification in Sweden. Forest Policy and Economics 13: 191198. - doi: 10.1016/j.forpol.2010.11.004

Kraxner F, Schepaschenko D, Fuss S, Lunnan A, Kindermann G, Aoki K, See L (2017). Mapping certified forests for sustainable management. A global tool for information improvement through participatory and collaborative mapping. Forest Policy and Economics 83: 10-18. doi: 10.1016/j.forpol.2017.04.014

Levers C, Verkerk PJ, Müller D, Verburg PH, Butsic $\mathrm{V}$, Leitão PJ, Lindner M, Kuemmerle T (2014). Drivers of forest harvesting intensity patterns in Europe. Forest Ecology and Management 315: 160-172. - doi: 10.1016/j.foreco.2013.12.030

Maesano M, Lasserre B, Masiero M, Tonti D, Marchetti M (2016). First Mapping of the main High Conservation Value Forests (HCVFs) at national scale: the case of Italy. Plant Biosystems 150 (2): 208-216. - doi: 10.1080/11263504.20 14.948524

Martín-Fernández S, Martinez-Falero E (2018). Sustainability assessment in forest management based on individual preferences. Journal of Environmental Management 206: 482-489. doi: 10.1016/j.jenvman.2017.10.057

Martínez-Vega J, Mili S, Echavarría P (2016). Assessing forest sustainability: evidence from Spanish provinces. Geoforum 70: 1-10. - doi: 10.1016/j.geoforum.2015.12.013

McDonald GT, Lane MB (2004). Converging global indicators for sustainable forest management. Forest Policy and Economics 6 (1): $63-$ 70. - doi: 10.1016/S1389-9341(02)00101-6

McFarlane BL, Boxall PC (2000). Factors influencing forest values and attitudes of two stakeholder groups: the case of the Foothills Model Forest, Alberta, Canada. Society and Natural Resources 13 (7): 649-661. - doi: 10.1080/089419 20050121927

Millennium Ecosystem Assessment (2005). Ecosystems and human well-being: synthesis. Island Press, Washington, DC, USA, pp. 137.

Papilla M (2013). Forest certification and trustâDifferent roles in different environments. For- 
est Policy and Economics 31: 37-43. - doi 10.1016/j.forpol.2012.10.005

Rametsteiner E, Kraxner F (2003). Europeans and their forests. What do Europeans think about forests and sustainable forest management. Ministerial Conference on the Protection of Forests in Europe, Liason Unit, Vienna, Austria, pp. 55.

Romero C, Putz FE, Guariguata MR, Sills EO, Cerutti PO, Lescuyer G (2013). An overview of current knowledge about the impacts of forest management certifiation: a proposed framework for its evaluation. Occasional Paper 91, CIFOR, Bogor, Indonesia, pp. 35. [online] URL: http://books.google.com/books?id=bZFDAgAA QBAJ

Sands R (2005). Forestry in a global context. CABI Publishing, Wallingford, UK, pp. 272.

Schall P, Ammer C (2013). How to quantify forest management intensity in Central European forests. European Journal of Forest Research 132: 379-396. - doi: 10.1007/s10342-013-0681-6
Secco L, Da Re R, Pettenella D, Gatto P (2015). Why and how to measure forest governance at local level: a set of indicators. Forest Policy and Economics 49: 57-71. - doi: 10.1016/j.forpol.2013. 07.006

UNFF-11 (2015). The forests we want: beyond 2015. Official document, United Nations Economic and Social Council, New York, USA, pp. 4. [online] URL: http://www.un.org/ga/search/ view_doc.asp?symbol=E/CN.18/2015/L.1/Rev.1 Vuletic D, Potocic N, Krajter S, Seletkovic I, Furst C, Makeschin F, Galic Z, Lorz C, Matijasic D, Zupanic M, Simoncic P, Vacik H (2010). How socio-economic conditions influence forest policy. Development in Central and South-East Europe. Environmental Management 46: 931940. - doi: 10.1007/s00267-010-9566-3

Whiteman A, Wickramasinghe A, Piña L (2015). Global trends in forest ownership, public income and expenditure on forestry and forestry employment. Forest Ecology and Management 352: 99-108. - doi: 10.1016/j.foreco.2015.04.011
Wijewardana D (2008). Criteria and indicators for sustainable forest management: the road travelled and the way ahead. Ecological Indicators 8: 115-122. - doi: 10.1016/j.ecolind.2006.11. 003

Yamada Y (2018). Can a regional-level forest management policy achieve sustainable forest management? Forest Policy and Economics 90: 82-89. - doi: 10.1016/j.forpol.2018.01.013

Zhao J, Xie D, Wang D, Deng H (2011). Current status and problems in certification of sustainable forest management in China. Environmental Management 48: 1086-1094. - doi: 10.1007/so 0267-011-9620-9

Zivojinović I, Weiss G, Lidestav G, Feliciano D, Hujala T, Dobšinská Z, Lawrence A, Nybakk E, Quiroga S, Schraml U (2015). Forest Land Ownership Change in Europe. COST Action FP1201 FACESMAP Country Reports, Joint Volume. EFICEEC-EFISEE Research Report, University of Natural Resources and Life Sciences, Vienna, Austria, pp. 693. 